\title{
Effect of Sprinkler Irrigation on Bacterial Soft Rot and Yield of Broccoli
}

\author{
R. L. Ludy and M. L. Powelson, Department of Botany and Plant Pathology, Oregon State University, Corvallis \\ 97331-2902; and D. D. Hemphill, Jr., North Willamette Research and Extension Center, 15210 N.E. Miley Rd., \\ Aurora, OR 97002-9543
}

\begin{abstract}
Ludy, R. L., Powelson, M. L., and Hemphill, D. D., Jr. 1997. Effect of sprinkler irrigation on bacterial soft rot and yield of broccoli. Plant Dis. 81:614-618.

The effect of amount of applied water under two irrigation frequencies (once versus three times per week) on the incidence of bacterial soft rot, caused by Erwinia carotovora subsp. carotovora, and yield of broccoli was investigated in field studies conducted in 1987 and 1988. At head initiation, the amount of applied water was varied by utilizing a line source irrigation system. Incidence of soft rot was higher in the OSU breeding line 86-3 plots, followed by cv. Citation and then cv. Gem. Soft rot was not consistently affected by amount of applied water. Differences in amount of disease were apparent, however, between the separate irrigation frequency studies in 1988; disease incidence more than doubled under the high- compared with the low-frequency irrigation. Further studies on the effects of frequency and timing of sprinkler irrigation on soft rot and yield of Gem broccoli were undertaken in 1993 and 1994. Six sprinkler irrigation regimes, a factorial combination of frequency (irrigation every 2, 4, or 8 days) and timing (morning or evening), were established. Total water applied did not differ by treatment. Incidence of soft rot was negligible at the first harvest in both years. At the last harvest, the incidence of soft rot was significantly reduced, from 22 to $10 \%$ in 1993 and from 30 to $15 \%$ in 1994, by the change in frequency of irrigation from 2 to 8 days. In contrast, timing of irrigation had no effect on disease incidence. Yield of broccoli was not affected by either frequency or timing of irrigation.
\end{abstract}

Bacterial soft rot of broccoli (Brassica oleracea L. var. italica Plenck) commonly occurs in the Willamette Valley of Oregon as well as in other broccoli production areas worldwide $(2,8,20)$. The disease affects both floret and stem tissues. It appears first as a water-soaked lesion followed by maceration and soft rotting of tissue. In the Willamette Valley, disease occurs mainly during periods of moderate temperatures and high relative humidity or rainfall

Several bacteria have been implicated as causal agents of bacterial head rot, and it is likely that a complex of bacterial pathogens is responsible $(8,20)$. Hildebrand (8) isolated many Pseudomonas species and Erwinia carotovora subsp. carotovora from diseased heads. Inoculations with pectolytic strains of Pseudomonas resulted in water-soaking and extensive rot. Other strains caused only water-soaking with no soft rot. When E. carotovora subsp. carotovora was coinoculated with these strains, extensive rot also occurred. In Oregon, $E$. carotovora subsp. carotovora is commonly recovered from symptomatic heads. When inoculated onto healthy heads under field

Corresponding author: R. L. Ludy

E-mail: ludyr@bcc.orst.edu

Accepted for publication 24 February 1997.

Publication no. D-1997-0423-07R

(C) 1997 The American Phytopathological Society conditions, disease frequently results. Although we recovered several species of Pseudomonas from diseased heads (R. L. Ludy and M. L. Powelson, unpublished), we have been unable to complete Koch's postulates. Although the etiology of bacterial soft rot is not completely understood, the development of effective control strategies continues.

Because chemical controls have not been consistently effective and resistant cultivars well-adapted to our local climate and acceptable to processors have not been identified, other cultural strategies for disease control warranted investigation. Sprinkler irrigation is necessary for broccoli production in the semiarid Pacific Northwest. Sprinkler irrigation, however, can also favor disease development by modifying the crop microclimate. Under sprinkler irrigation, increased relative humidity, decreased temperatures, and longer diurnal dew periods have been measured in the crop canopy $(4,14)$. These changes favor bacterial growth and disease development. Thus, adjustments to irrigation practices during broccoli heading may provide some control for disease. Irrigation also must be adequate during head initiation and enlargement for satisfactory yields of broccoli (17). Better management of bacterial soft rot in Oregon requires more specific knowledge of irrigation effects on disease development and yield.

The purpose of this study was to determine the effects of amount of water applied under two irrigation frequencies and the effects of irrigation frequency and time of day of irrigation, at equal amounts of applied water, on bacterial soft rot and yield of broccoli.

\section{MATERIALS AND METHODS}

Amount of applied water study. Field plots were established in 1987 and 1988 at the North Willamette Research and Extension Center, Aurora. The broccoli cultivars Gem and Citation and the broccoli breeding line OSU 86-3 were seeded during the last week of June of each year into $3.8-\mathrm{cm}$ cells containing a medium of peat, pumice, and shredded bark (1:1:2, vol/vol/vol). Seedlings were fertilized weekly with a water-soluble $20 \mathrm{~N}-8.7 \mathrm{P}-16.7 \mathrm{~K}$ fertilizer containing micronutrients and grown in an unheated greenhouse until transplanted to the field during the last week of July.

The plot area consisted of a Willamette silt loam to which $5.0 \mathrm{~kg}$ of boron, $0.84 \mathrm{~kg}$ of trifluralin, $1.5 \mathrm{~kg}$ of chlorpyrifos, and $1,120 \mathrm{~kg}$ of $10 \mathrm{~N}-8.7 \mathrm{P}-16.7 \mathrm{~K}$ fertilizer per ha were applied 1 week before transplanting. An additional $168 \mathrm{~kg}$ of N/ha was side-dressed as ammonium nitrate 3 weeks after transplanting. On 3 September 1987, Bacillus thuringiensis $(0.28 \mathrm{~kg} / \mathrm{ha})$ was applied to control cabbage loopers, and on 4 August 1988, carbaryl $(1.1 \mathrm{~kg} / \mathrm{ha})$ was applied to control spotted cucumber beetles. A 10-row border of corn (Zea mays) was planted in late May at the perimeter of the plot area to reduce the influence of wind on the irrigation spray pattern.

Each plot consisted of a four-row bed, $3.7 \mathrm{~m}$ long, parallel to the irrigation line. Seedlings were spaced $24 \mathrm{~cm}$ apart within rows on $41-\mathrm{cm}$ centers. All plots were sprinkler-irrigated as needed and received equal amounts of water until 1 week before head initiation. At that time, two irrigation frequency experiments were established with a line-source irrigation system: the low-frequency experiment was watered once per week for $7 \mathrm{~h}$; the high-frequency experiment was watered three times per week for approximately $2.5 \mathrm{~h}$ per irrigation. When rainfall occurred, 3 and 4 days in 1987 and 1988, respectively, the duration of the irrigation for that week was reduced to compensate.

The line-source sprinkler irrigation system consisted of sprinkler heads placed on $60-\mathrm{cm}$ risers spaced $12.2 \mathrm{~m}$ apart in each frequency experiment. In 1987, the plots were centered at 4,6 , and $8 \mathrm{~m}$ perpendicular from one side of the irrigation line. Catch cans $(11 \times 13.5 \mathrm{~cm}$ deep $)$, placed at 
three distances from the line source, were used to estimate the amount of water applied. In 1988, water applied was measured after each irrigation from catch cans placed in each plot. Plots were centered at 2, 4, 6, and $8 \mathrm{~m}$ perpendicular from both sides of the irrigation line. The farther a plot was from the irrigation line, the less water the plot received (6).

A strain of E. carotovora subsp. carotovora, isolated from a broccoli head with soft rot symptoms, was used to inoculate the field plots. Inoculum was grown on King's B medium (9) for $48 \mathrm{~h}$ at 20 to $22^{\circ} \mathrm{C}$. An aqueous cell suspension of $10^{6}$ cells per ml of water was prepared and applied to the plots with a $\mathrm{CO}_{2}$ pressurized backpack sprayer at 4-day intervals beginning at head initiation and ending at the second harvest.

Leaf wetness sensors attached to ring stands were placed in the center of 16 plots in the high-frequency irrigation experiment. Four sensors were placed in the broccoli canopy at the height of developing heads at each of the four distances from the irrigation line. The sensors were connected to 21X microloggers (Campbell Scientific, Inc., Logan, UT), which recorded the duration of leaf wetness from the time the irrigation regimes were established to the last harvest.

At weekly intervals beginning 28 September, mature heads from the two center rows were harvested and weighed, and the numbers of heads with and without symptoms of soft rot were recorded. Plots were harvested three times in 1987 and four times in 1988.

The experimental design was a modified split-block $(7,12)$. Each combination of cultivar and distance from the irrigation line was replicated six times. For statistical analysis, cultivars were the main plots and amount of irrigation water applied was the subplot. Amount of water applied at each distance could not be randomized due to limitations of the line-source irrigation treatment providing a continuous variable. Data were analyzed to test cultivar and cultivar $x$ irrigation-amount interactions (7).

Irrigation frequency study. Field plots were established at the same research station, with plot preparation and maintenance as described above. The broccoli cultivar Gem was direct seeded on 6 July in both 1993 and 1994. Three weeks after emergence, plants were thinned to $25 \mathrm{~cm}$ between plants. Each plot consisted of 18 6-m-long rows on 50-cm centers. Plots were isolated from each other by $9 \mathrm{~m}$ of fallow land in all directions.

In 1993, the experimental design was a randomized block with a $2 \times 2$ factorial combination of irrigation frequency (every 2 or 8 days) and timing (morning or evening) for a total of four treatments. In 1994, there were three frequencies (every 2, 4, or 8 days) and morning or evening irrigation for a total of six treatments. In both years, treatments were replicated four times.

The irrigation system was constructed from a flexible hose that connected the four replicate plots of each treatment. A separate valve controlled the activity of each treatment. The duration of the irrigation treatments $(1 / 2,1$, or $2 \mathrm{~h})$ was designed to deliver 1,2 , or $4 \mathrm{~cm}$ of water for the 2-, 4-, or 8-day frequency, respectively. The 1/2-h irrigation commenced at 8:30 a.m. or $6: 30$ p.m. The longer irrigations commenced at correspondingly earlier times, with all irrigation terminating by 9 a.m. or 7 p.m. Water was applied from two sprinklers located at each end of each plot. Rain gauges were located in the center of each plot. Water accumulation was meas-

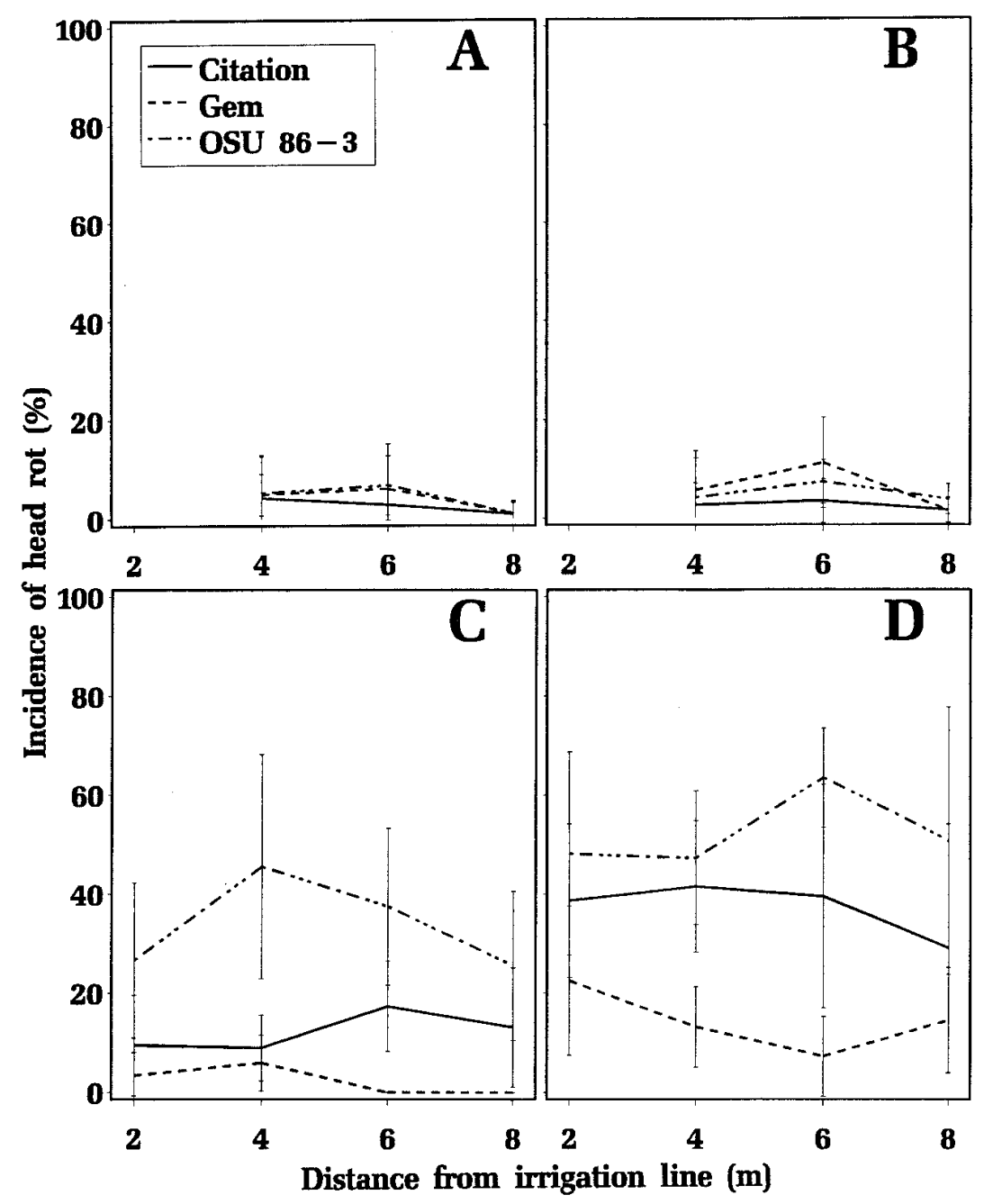

Fig. 1. Influence of amount of applied water on incidence of bacterial soft rot in three broccoli cultivars under (A) low-frequency and (B) high-frequency irrigation in 1987, and under (C) low-frequency and (D) high-frequency irrigation in 1988. Error bars give one standard error of the mean. In 1987 (A and B), the amounts of water applied were $11.3,8.3$, and $4.8 \mathrm{~cm}$ at 4,6 , and $8 \mathrm{~m}$, respectively. In 1988 under low-frequency irrigation (C), the amounts of water applied were 12.4, 11.8, 11.3 , and $8.9 \mathrm{~cm}$ at $2,4,6$, and $8 \mathrm{~m}$, respectively. In 1988 under high-frequency irrigation (D), the amounts of water applied were $12.9,12.5,10.2$, and $7.0 \mathrm{~cm}$ at $2,4,6$, and $8 \mathrm{~m}$, respectively.

Table 1. Incidence of bacterial soft rot in three broccoli cultivars grown under two irrigation frequencies $^{\mathrm{x}}$

\begin{tabular}{|c|c|c|c|c|}
\hline \multirow[b]{2}{*}{ Cultivar } & \multicolumn{2}{|c|}{ High frequency } & \multicolumn{2}{|c|}{ Low frequency } \\
\hline & $1987(\%)^{\mathrm{y}}$ & $1988(\%)^{y}$ & $1987(\%)^{\mathrm{y}}$ & $1988(\%)^{y}$ \\
\hline Gem & $6.2 \mathrm{a}^{\mathrm{z}}$ & $14.4 \mathrm{c}$ & $4.0 \mathrm{a}$ & $2.3 \mathrm{~b}$ \\
\hline Citation & $2.6 \mathrm{a}$ & $37.2 \mathrm{~b}$ & $2.7 \mathrm{a}$ & $12.2 \mathrm{~b}$ \\
\hline OSU 86-3 & $5.1 \mathrm{a}$ & $52.4 \mathrm{a}$ & $4.4 \mathrm{a}$ & $33.8 \mathrm{a}$ \\
\hline
\end{tabular}

${ }^{\mathrm{x}}$ Irrigation occurred three times per week in the high-frequency experiment and once per week in the low-frequency experiment.

${ }^{y}$ Values presented are the sum of all harvests.

${ }^{\mathrm{z}}$ Means among cultivars within columns followed by the same letter do not differ significantly according to Fisher's protected least significance difference $(P=0.05)$. 
ured immediately after each irrigation or rainfall.

Prior to initiation of irrigation treatments, plots were irrigated uniformly as needed, about $3 \mathrm{~cm} /$ week in 1993 and 4 $\mathrm{cm} /$ week in 1994. The irrigation treatments were initiated when broccoli heads were 5 $\mathrm{cm}$ in diameter, which occurred on 17 and 8 September in 1993 and 1994, respectively.
Inoculum was prepared as previously stated. Plots were inoculated on 16 and 23 September and 13 and 21 September in 1993 and 1994, respectively.

Leaf wetness duration was measured in four plots, which were representative of the frequency and timing of the irrigation treatments (morning and evening of the 2and 8-day irrigation frequencies). Four replicate sensors were placed in each plot

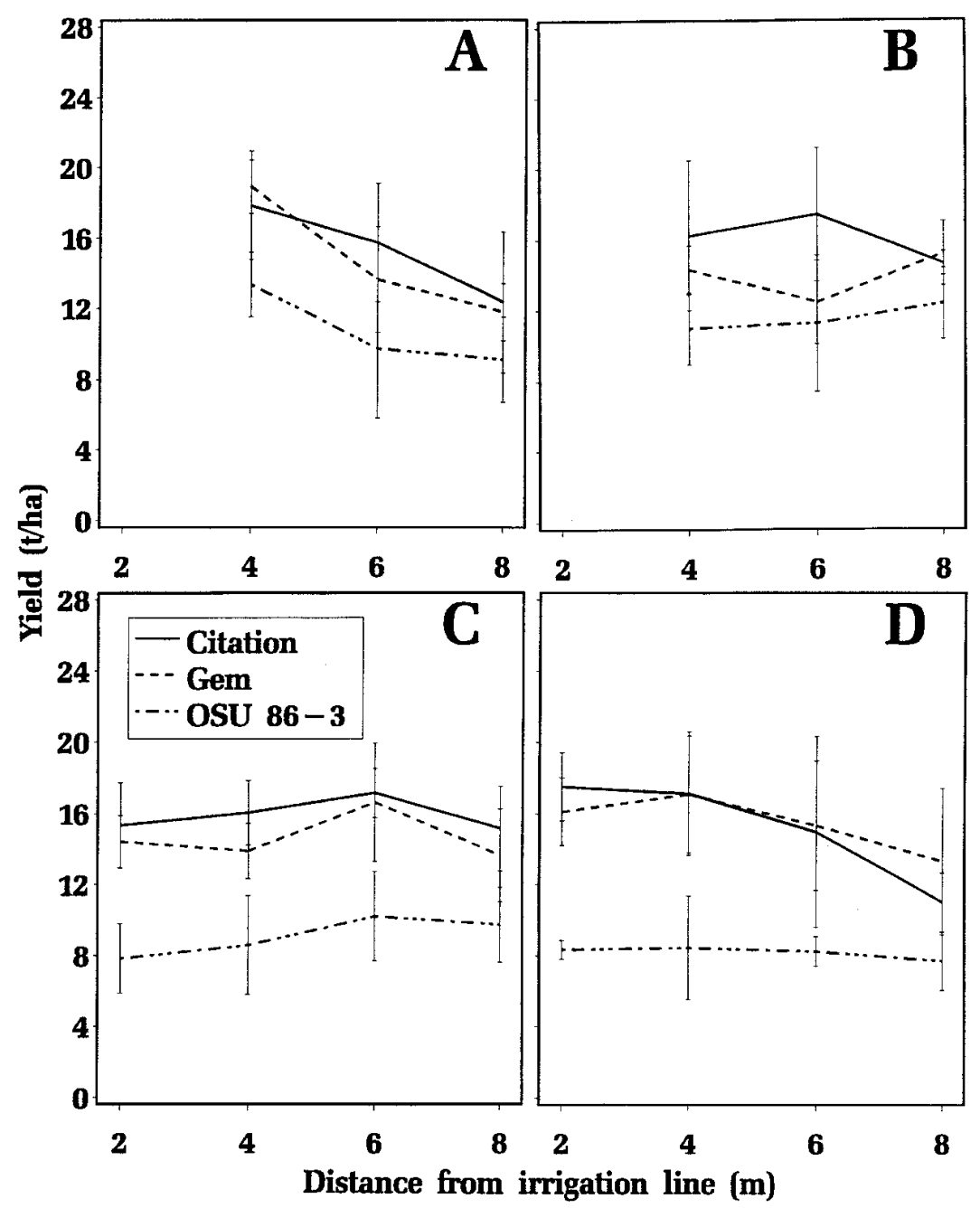

Fig. 2. Influence of amount of applied water on yield of three broccoli cultivars under (A) low-frequency and (B) high-frequency irrigation in 1987, and under (C) low-frequency and (D) high-frequency irrigation in 1988. Error bars give one standard error of the mean. In 1987 (A and B), the amounts of water applied were $11.3,8.3$, and $4.8 \mathrm{~cm}$ at 4,6 , and $8 \mathrm{~m}$, respectively. In 1988 under low-frequency irrigation (C), the amounts of water applied were $12.4,11.8,11.3$, and $8.9 \mathrm{~cm}$ at 2,4 , 6 , and $8 \mathrm{~m}$, respectively. In 1988 under high-frequency irrigation (D), the amounts of water applied were $12.9,12.5,10.2$, and $7.0 \mathrm{~cm}$ at $2,4,6$, and $8 \mathrm{~m}$, respectively.

Table 2. Yield of three broccoli cultivars grown under two irrigation frequencies ${ }^{\mathrm{x}}$

\begin{tabular}{lccccc}
\hline & \multicolumn{2}{c}{ High frequency } & & \multicolumn{2}{c}{ Low frequency } \\
\cline { 2 - 3 } \cline { 5 - 6 } Cultivar & $\mathbf{1 9 8 7}(\mathbf{t} / \mathbf{h a})^{\mathbf{y}}$ & $\mathbf{1 9 8 8}(\mathbf{t} / \mathbf{h a})^{\mathbf{y}}$ & & $\mathbf{1 9 8 7}(\mathbf{t} / \mathbf{h a})^{\mathbf{y}}$ & $\mathbf{1 9 8 8}(\mathbf{t} / \mathbf{h a})^{\mathbf{y}}$ \\
\hline Gem & $14.0 \mathrm{ab}^{\mathrm{z}}$ & $15.5 \mathrm{a}$ & & $14.8 \mathrm{a}$ & $14.6 \mathrm{a}$ \\
Citation & $16.1 \mathrm{a}$ & $15.2 \mathrm{a}$ & & $15.3 \mathrm{a}$ & $15.9 \mathrm{a}$ \\
OSU 86-3 & $11.5 \mathrm{~b}$ & $8.2 \mathrm{~b}$ & & $10.7 \mathrm{~b}$ & $9.1 \mathrm{~b}$ \\
\hline
\end{tabular}

${ }^{\mathrm{x}}$ Irrigation occurred three times per week in the high-frequency experiment and once per week in the low-frequency experiment.

${ }^{y}$ Values presented are the sum of all harvests.

${ }^{z}$ Means among cultivars within columns followed by the same letter do not differ significantly according to Fisher's protected least significant difference $(P=0.05)$. in the center of the canopy. In 1993, volumetric soil water content was monitored by time domain reflectometry (TDR) (Soil Moisture Corp., Goleta, CA). Three readings were taken in each main plot at 2 p.m. each day from 17 September until 1 October.

A three-row bed was randomly selected from each plot for each harvest date. Harvest occurred on 28 September and 4 and 8 October in 1993 and 19 and 29 September in 1994. At each harvest, weight and number of heads with and without bacterial soft rot symptoms were recorded. Data from individual harvests were analyzed as a $2 \times$ 2 or $3 \times 2$ factorial in 1993 and 1994, respectively.

\section{RESULTS}

Amount of applied water study. Increasing the amount of water applied during heading had no consistent effect on the incidence of soft rot for the three cultivars under the amounts of water tested (Fig. 1). In addition, there was no significant cultivar $\times$ amount of water interaction. In 1988, although amount of applied water appeared to have little effect on amount of disease, differences in the incidence of soft rot were apparent between the separate irrigation frequency experiments. The overall incidence of soft rot was $34.6 \%$ under highfrequency compared with $16.1 \%$ under low-frequency irrigation.

Incidence of bacterial soft rot differed significantly among cultivars in 1988, but not in 1987 when disease incidence was low (Table 1). More rainfall occurred in 1988, possibly contributing to more disease. Under both high- and low-frequency irrigation, OSU 86-3 had significantly more disease overall than did $\mathrm{Gem}$ or $\mathrm{Ci}$ tation. For all cultivars, incidence of soft rot increased with successive harvests in both years. In 1987, overall incidence of soft rot was $1.5,3.6$, and $6.2 \%$ for the first, second, and third harvests, respectively. In 1988, overall incidence of soft rot was 0.1 , 9.0, 40.9, and $29.0 \%$ for the first, second, third, and fourth harvests, respectively.

The amount of water applied during heading did not have a consistent effect on yield under the two irrigation frequencies. Yield appeared to increase as the amount of water applied during the treatment period increased from 4.8 to $11.3 \mathrm{~cm}$ under low-frequency but not under high-frequency irrigation in 1987 (Fig. 2). There was a significant cultivar $\times$ amount of water interaction under high-frequency irrigation. Citation had significantly higher yields at $8.3 \mathrm{~cm}(6 \mathrm{~m})$ than did Gem; whereas no significant difference was measured at $4.8 \mathrm{~cm}(4 \mathrm{~m})$ and $11.3 \mathrm{~cm}(8$ m). In contrast, yield of OSU 86-3 was not significantly different across amounts of water. In 1988, there was no significant interaction, and no strong trends were observed with increases in water applied from 7.0 to $12.9 \mathrm{~cm}$ under high-frequency 
and from 8.9 to $12.4 \mathrm{~cm}$ under the lowfrequency irrigation.

Overall yields were similar between frequency experiments and years, except for OSU 86-3, which yielded more in 1987 than in 1988 due to a loss in plant stand from root maggot feeding (Table 2). Yield differed significantly among cultivars. Gem and Citation consistently produced higher yields than did OSU 86-3 regardless of irrigation frequency or year. In addition, Gem matured earliest, followed by Citation and then OSU 86-3.

Irrigation frequency study. Incidence of bacterial soft rot at the first harvest was 0 and $0.2 \%$ in 1993 and 1994, respectively. At the last harvest in both years, soft rot incidence was reduced by half in the 8-day compared with the 2-day irrigation treatment (Tables 3 and 4). Timing of irrigation (morning versus evening) did not significantly affect soft rot incidence. Yield did not differ with either frequency or timing of irrigation at all harvests in both years. Because there were no significant irrigation frequency $\times$ timing interactions affecting either soft rot or yield, only main effects were presented in tables.

Mean amount of water applied to plots averaged 0.5 and $0.7 \mathrm{~cm} /$ day in 1993 and 1994, respectively, during the treatment period and did not differ significantly with treatment. The amount of water applied in 1994 included 3 days of recorded rainfall.

From 3 to 12 days after initiation of the irrigation treatments in 1993, percent soil moisture by volume was highly variable (3.5 to $29.7 \%$ ) but did not differ significantly among treatments. On day 13 and 14 , percent soil moisture was $47 \%$ greater in the 2-day compared with the 8-day frequency treatment.

In 1993, the duration of leaf wetness (average hours per day leaves remained wet) was longer in the 2-day $(15.1 \mathrm{~h}) \mathrm{com}$ pared with the 8-day $(13.0 \mathrm{~h})$ treatment and only slightly longer in the evening (14.1 h) compared with the morning $(13.1 \mathrm{~h})$ treatment. In 1994, leaf wetness duration for the 2-day morning treatment $(8.8 \mathrm{~h})$ was shorter, and the 2-day evening treatment $(11.5 \mathrm{~h})$ was longer than the morning or evening 8-day treatments $(10.1$ or $10.3 \mathrm{~h}$, respectively). In 1993, the duration of leaf wetness gradually increased as the season progressed; in 1994, the duration of leaf wetness varied more day-to-day than in 1993.

\section{DISCUSSION}

Irrigation frequency had an impact on bacterial soft rot but not on total yield; thus, when the incidence of soft rot increased, marketable yield decreased. The incidence of head rot was reduced by half when frequency was reduced from 2 to 8 days in 1993 and 1994. In addition, a reduction in disease was observed under weekly compared with three times per week irrigation for all cultivars in 1988 when disease incidence was high. In contrast, neither amount of applied water nor timing (morning versus evening irrigation) had a consistent effect on incidence of soft rot or yield of broccoli.

Frequent irrigations with sprinklers are known to favor many diseases. For example, late blight of potatoes was less severe in plots receiving three to four irrigations at 21- to 28-day intervals than in plots receiving 8 to 11 overhead irrigations at 7 to 10-day intervals (16). Few studies have reported on the effects of timing of sprinkler irrigation or amount of water applied on disease. Rotem et al. (15) found that under environmental conditions marginal for development of late blight, the disease was favored by morning compared with afternoon or evening irrigations. Sporangia of Phytophthora infestans were readily dispersed only with morning irrigations because sporangia were unable to survive the adverse environmental conditions that occurred later in the day.

Sprinkler irrigation influences disease development by modifying the microclimate and especially by providing free moisture. Diseases caused by the soft rot erwinias are highly influenced by the presence of free moisture at the infection site. Survival and reproduction of populations of soft rot erwinias are favored by wet leaf surfaces, and these populations decline rapidly as leaf surfaces dry. In field studies, Pérombelon (13) detected E. carotovora as long as the plant surface remained wet, but could not detect the bacterium 1 to 2 days after the plant surface dried. In another study, leaf lesions and epiphytic populations of Pseudomonas syringae pv. tomato increased during moist, cool conditions on tomato plants but declined rapidly as the presence of free moisture declined (18).

Although exact moisture requirements for initiation of soft rot of broccoli by $E$. carotovora subsp. carotovora have not yet been defined, these parameters have been elucidated for bacterial soft rot of potatoes. With potato tubers, decay will occur under conditions of oxygen depletion $(5,10)$. A film of water can cause the tubers to become deficient in oxygen in a relatively

Table 3. Effects of frequency and timing of irrigation on bacterial soft rot and yield of broccoli at the last once-over harvest in 1993

\begin{tabular}{lcc}
\hline $\begin{array}{l}\text { Irrigation } \\
\text { treatment }\end{array}$ & $\begin{array}{c}\text { Heads with } \\
\text { soft rot }(\boldsymbol{\%})\end{array}$ & $\begin{array}{c}\text { Total yield } \\
(\mathbf{t} / \mathbf{h a})\end{array}$ \\
\hline Frequency & & \\
2-day interval & 22.0 & 25.5 \\
8-day interval & 10.1 & 24.3 \\
& $* \mathrm{z}$ & $\mathrm{NS}$ \\
Timing & & \\
Morning & 13.7 & 26.3 \\
Evening & 18.8 & 23.5 \\
& $\mathrm{NS}$ & $\mathrm{NS}$ \\
\hline
\end{tabular}

$\mathrm{z} *$ or NS, analysis of variance $F$ values of main effects were significant at $P=0.05$ or not significant, respectively. short period of time because of internal respiration requirements (1). If oxygen levels decrease below normal concentrations and remain low, the host's ability to resist the pathogen may be compromised and decay begins. The same effect could be important in the development of soft rot of broccoli when free moisture collects on the developing head, especially when fields are irrigated frequently by overhead sprinklers or subjected to prolonged dew periods.

Leaf wetness sensors were scattered throughout the plots to measure the presence and duration of free moisture on the plant surface. Sensors often registered initial leaf wetness between 6 p.m. and midnight, and wetness continued until 9 to 11 a.m. the next day. This long period of leaf wetness occurred regularly because of the prevalence of diurnal dew periods and early morning fog in the late summer and fall in the Willamette Valley. Sprinkling prolonged moisture periods, as evidenced by the longer durations of leaf wetness measured under 2-day compared with 8day irrigations. In addition, free moisture tended to be present longer under evening compared with morning irrigation. In 1994, differences were not so easily explained; however, only single plots were represented due to limitations of equipment. Duration of leaf wetness was longest with the 2-day $\times$ evening treatment and shortest with the 2-day $\times$ morning treatment. Duration of leaf wetness for the 8-day treatments fell between these two treatments. In the amount of water applied study, the duration of leaf wetness was similar (12.7 h) at all distances from the irrigation line.

Although leaf wetness measurements provide evidence of the role free moisture plays on disease development, the leaf wetness measurements may not accurately reflect conditions on a developing broccoli head. The ability of a broccoli head to retain moisture may be different than that of leaves. In grapes, the architecture of a grape cluster dramatically affects the retention of moisture. The tighter the cluster,

Table 4. Effects of frequency and timing of irrigation on bacterial soft rot and yield of broccoli at the last once-over harvest in 1994

\begin{tabular}{lcc}
$\begin{array}{l}\text { Irrigation } \\
\text { treatment }\end{array}$ & $\begin{array}{c}\text { Heads with } \\
\text { soft rot } \mathbf{\%})\end{array}$ & $\begin{array}{c}\text { Total yield } \\
\text { (t/ha) }\end{array}$ \\
\hline Frequency & & \\
2-day interval & $30.4 \mathrm{a}^{\mathrm{y}}$ & 22.4 \\
4-day interval & $18.4 \mathrm{ab}$ & 25.0 \\
8-day interval & $15.3 \mathrm{~b}$ & 21.8 \\
& & $\mathrm{NS}^{\mathrm{z}}$ \\
Timing & & \\
Morning & 21.7 & 23.0 \\
Evening & 21.4 & 23.1 \\
& $\mathrm{NS}$ & $\mathrm{NS}$ \\
\hline
\end{tabular}

y Means followed by the same letter are not significantly different according to Fisher's protected least significant difference $(P=$ 0.01).

${ }^{\mathrm{z}}$ NS, Analysis of variance $F$ values of main effects were not significant. 
the slower the evaporation of water from the surface of the grapes. These tighter grape clusters were more susceptible to Botrytis rot (19). In addition, where berries were in close contact, there was a reduced deposition of cuticle and epicuticular wax (11). Canaday (2) reported that tightness, doming, and looseness of broccoli heads were traits valuable in predicting bacterial soft rot. We did not measure horticultural characteristics of the cultivars in this study, but the tightness and doming of the head may play an important role in cultivar susceptibility and the degree to which the head retains moisture.

The three cultivars, Gem, Citation, and OSU 86-3, had significantly different incidences of soft rot; however, these cultivars also differed in length of time from transplant to maturity. The later the cultivar matured, the greater the incidence of disease. It is difficult to separate the effect of inherent differences in cultivar susceptibility from the effect of different environmental conditions prevalent when the heads were developing. Canaday et al. (3) staggered plantings of broccoli genotypes to allow for simultaneous harvest dates and found an inverse correlation between days to maturity and incidence of soft rot. They hypothesize that the days required for broccoli genotypes to reach maturity may be linked to horticultural characteristics associated with soft rot resistance. One factor that has not been addressed is the time from head initiation to maturation rather than total days to maturity. Broccoli heads developing over a longer period of time may appear more susceptible because there was more opportunity for disease to occur. Planting resistant cultivars combined with well-timed irrigation practices is currently the best strategy to minimize losses from bacterial soft rot.

\section{LITERATURE CITED}

1. Burton, W., and Wigginton, M. J. 1970. The effect of a film of water upon the oxygen status of a potato tuber. Potato Res. 13:180-186.

2. Canaday, C. H. 1989. Identification of horticultural traits for predicting broccoli cultivar susceptibility to bacterial soft rot. (Abstr.) Phytopathology 79:1160.

3. Canaday, C. H., Wyatt, J. E., and Mullins, J. A. 1991. Resistance in broccoli to bacterial soft rot caused by Pseudomonas marginalis and fluorescent Pseudomonas species. Plant Dis. 75:715-720.

4. Crandall, P. C., Jensen, M. C., Chamberlain, J. D., and James, L. G. 1971. Effect of row width and mist irrigation on the microclimate of bush beans. HortScience 6:345-347.

5. De Boer, S. H., and Kelman, A. 1978. Influence of oxygen concentration and storage factors on susceptibility of potato tubers to bacterial soft rot (Erwinia carotovora). Potato Res. 21:65-80.

6. Hanks, R. J., Keller, J., Rasmussen, V. P., and Wilson, G. D. 1976. Line source sprinkler for continuous variable irrigation-crop production studies. Soil Sci. Soc. Am. J. 40:426-429.

7. Hanks, R. J., Sisson, D. V., Hurst, R. L., and Hubbard, K. G. 1980. Statistical analysis of results from irrigation experiments using the line-source sprinkler system. Soil Sci. Soc. Am. J. 44:886-888.

8. Hildebrand, P. D. 1989. Surfactant-like characteristics and identity of bacteria associated with broccoli head rot in Atlantic Canada. Can. J. Plant Pathol. 11:205-214.

9. King, E. O., Ward, M. K., and Raney, D. E. 1954. Two simple media for the demonstration of pyocyanin and fluorescein. J. Lab. Clin. Med. 44:301-307.
10. Maher, E. A., and Kelman, A. 1983. Oxygen status of potato tuber tissue in relation to maceration by pectic enzymes of Erwinia carotovora. Phytopathology 73:536-539.

11. Marois, J. J., Nelson, J. K., Morrison, J. C., Lile, L. S., and Bledsoe, A. M. 1986. The influence of berry contact within grape clusters on the development of Botrytis cinerea and epicuticular wax. Am. J. Enol. Vitic. 37:293-296.

12. Miller, D. E., and Burke, D. W. 1983. Response of dry beans to daily deficit sprinkler irrigation. Agron. J. 75:775-778.

13. Pérombelon, M. C. M. 1978. Contamination of potato crops by air-borne Erwinia carotovora. Pages 411-431 in: Microbial Ecology of the Phylloplane. J. P. Blakeman, ed Academic Press, London.

14. Rotem, J., and Palti, J. 1969. Irrigation and plant disease. Annu. Rev. Phytopathol. 7:267288.

15. Rotem, J., Palti, J., and Lomis, J. 1970. Effects of sprinkler irrigation at various times of the day on development of potato late blight. Phytopathology 60:839-843.

16. Rotem, J., Palti, J., and Rawitz, E. 1962. Effect of irrigation method and frequency on development of Phytophthora infestans on potatoes under arid conditions. Plant Dis. Rep. 46:145-149.

17. Singh, R., and Alderfer, R. B. 1966. Effects of soil-moisture stress at different periods of growth of some vegetable crops. Soil Sci. 101:69-80.

18. Smitley, D. R., and McCarter, S. M. 1982. Spread of Pseudomonas syringae pv. tomato and role of epiphytic populations and environmental conditions in disease development. Plant Dis. 66:713-717.

19. Vail, M. E., and Marois J. J. 1991. Grape cluster architecture and the susceptibility of berries to Botrytis cinerea. Phytopathology 81:188-191.

20. Wimalajeewa, D. L. S., Hallam, N. D., Hayward, A. C., and Price, T. V. 1987. The etiology of head rot disease of broccoli. Aust. J. Agric. Res. 38:735-742 